\title{
ANALISIS PENGARUH PROMOSI TERHADAP PENJUALAN SUKU CADANG PADA BENGKEL JAKARTA KECAMATAN SUKAMAJU
}

\author{
Salju $^{1}$, Hadrah $^{2}$, Risa Melati ${ }^{3}$ \\ 1) Sekolah Tinggi Ilmu Ekonomi Muhammadiyah Palopo \\ ${ }^{2,3)}$ Prodi Akuntansi Sekolah Tinggi Ilmu Ekonomi Muhammadiyah Palopo
}

\begin{abstract}
Abstrak: Tujuan Penelitian ini untuk mengetahui penjualan suku cadang pada Bengkel Jakarta Kecamatan Sukamaju dipengaruhi oleh promosi. Tujuan penelitian adalah untuk mengetahui seberapa besar pengaruh promosi terhadap hasil penjualan pada Bengkel "Jakarta "Kecamatan Sukamaju.

Data dalam penelitian ini merupakan data sekunder yang diperoleh dari data biaya promosi dan penjualan pada Bengkel Jakarta Kecamatan Sukamaju yang sekaligus dijadikan sampel penelitian. Analisis yang digunakan untuk menguji hipotesis adalah regresi sederhana, dengan alat bantu SPSS 18.

Hasil penelitian ini menunjukkan Secara parsial variabel biaya promosi dari hasil perhitungan diperoleh angka t hitung sebesar 14,237 > t tabel 12,706 sehingga Ha diterima dan Ho ditolak. Artinya ada hubungan linier antara variabel biaya promosi terhadap penjualan, yaitu 0,998 atau 99,8\% dianggap signifikan. Secara simultan variabel biaya promosi berpengaruh secara signifikan terhadap penjualan sebesar 203,714 dengan signifikansi 0,045. Hipotesis penelitiaan ini yang menduga bahwa promosi mempunyai pengaruh yang signifikan terhadap hasil penjualan Suku Cadang Pada Bengkel "Jakarta “ Sukamaju adalah terbukti kebenarannya.

Kesimpulan dari hasil penelitian ini adalah secara parsial faktor biaya promosi berpengaruh terhadap penjualan suku cadang pada Bengkel Jakarta Kecamatan Sukamaju, Diharapkan agar kiranya pimpinan Benkel Jakarta Kecamatan Sukamaju terus memperhatikan faktor biaya promosi untuk lebih meningkatkan lagi penjualan suku cadang, kiranya penelitian ini bisa dilanjutkan kembali dengan berfokus pada variabel yang belum diteliti.
\end{abstract}

Kata Kunci: Promosi dan Penjualan Suku Cadang.

\section{PENDAHULUAN}

Sejalan dengan pesatnya perkembangan teknologi dan ilmu pengetahuan di berbagai bidang sangat pesat, mempengaruhi lingkungan pasar dengan dipasarkannya berbagai produk berteknologi tinggi. Perusahaan sebagai lembaga perdagangan berperan serta dalam pembangunan ekonomi dan menyediakan kebutuhan masyarakat baik yang berupa barang maupun jasa, dan pihak lain perusahaan memperoleh keuntungan yang merupakan sumber pendapatan negara untuk kelancaran pembangunan.

Dengan kemajuan teknologi maka dapat dipastikan adanya persaingan yang semakin ketat, sehingga dalam menjalankan usahanya, perusahaan selalu dituntut agar terus mengkaji konsep pemasaran yang lebih baik sehingga mampu bersaing dan mengikuti selera serta perilaku konsumen. Tujuannya adalah untuk memberikan kepuasan kepada konsumen dan masyarakat lainnya dalam pertukaran barang maupun jasa agar mendapatkan laba yang diharapkan.

Untuk dapat bertahan dan terus berkembang, perusahaan harus mengantisipasi keadaan persaingan yang semakin ketat pada saat ini. Perusahaan ingin berhasil dalam arti mampu memperoleh laba untuk mempertahankan kelangsungan hidupnya, maka perusahaan harus mampu menyesuaikan diri dan menciptakan ideide untuk mampu menyesuaikan diri dan menciptakan ide-ide untuk perkembangannya dan perusahaan juga harus mampu membuat strategi pemasaran yang tepat dan efektif. Strategi pemasaran bukanlah merupakan sejumlah tindakan 
khusus, tetapi merupakan pernyataan yang menunjukkan usaha pokok yang diarahkan untuk mencapai tujuan. Strategi pemasaran itu terdiri dari unsur-unsur pemasaran terpadu yaitu product, price, place dan promotion, yang selalu berkembang sejalan dengan gerak perusahaan dan lingkungan pemasaran serta perubahan perilaku konsumen.

Dalam menjalankan pemasaran, bagian pemasaran memegang peranan yang sangat penting bagi kelangsungan hidup suatu perusahaan dalam mencapai tujuannya dengan menyusun dan menetapkan strategi pemasaran yang tepat dan efektif. Strategi pemasaran yang dipakai harus dikembangkan sesuai dengan perkembangan pasar yang dituju dengan memberikan gambaran yang jelas dan terarah tentang apa yang dilakukan oleh perusahaan pada setiap kesempatan atau peluang yang ada.

Dengan melihat perkembangan yang pesat pada bidang teknologi, maka suatu perusahaan khususnya perusahaan industri di Indonesia baik industri besar maupun industri kecil akan saling merebut pasar. Demikian juga halnya perusahaan industri kecil penjualan suku cadang motor di indonesia. Meskipun perkembangan masih berada pada tahap perakitan, namun mampu memberikan peluang yang besar di pasaran dan sebagai sarana alat transportasi roda dua (motor) di Indonesia. Perkembangan yang dimaksud adalah perkembangan industri kendaraan roda dua ( motor ) yang ditunjang dengan bertambah luasnya sarana jalan dan pendapatan masyarakat yang meningkat. Akibat peluang yang ada maka jenis, model, dan merk yang beredar di Indonesia beraneka ragam. Oleh karena itu perusahaan dihadapkan pada persoalan bagaimana suku cadang kendaraan roda dua ( motor ) yang dipasarkan mampu menarik minat konsumen dengan meningkatkan stretegi promosi.

Sehubungan dengan hal tersebut di atas, perusahaan industri kecil " Bengkel Jakarta “ Kecamatan Sukamaju sebagai perusahaan yang bergerak dalam bidang usaha pemasaran berbagai jenis suku cadang kendaraan roda dua ( motor ), tak lepas dari tantangan dan harapan yang ingin dicapai dalam persaingan memperebutkan pangsa pasar guna meningkatkan hasil penjualan.

Untuk mempromosikan suatu barang tentu memerlukan biaya yang tidak sedikit, biaya yang dikeluarkan harus dapat meningkatkan hasil penjualan sehingga ada korelasi positif antara biaya promosi dengan hasil penjualan.

\section{BAHAN DAN METODE}

sumber yang digunakan dalam penulisan ini adalah data sekunder, yaitu data yang diperoleh dari dokumen serta bahan tertulis baik didalam maupun diluar perusahaan yang berkaitan dengan masalah yang dibahas untuk mendukung penulis. Dimana data yang diperoleh dari data biaya promosi dan penjualan pada Bengkel Jakarta Kecamatan Sukamaju yang sekaligus dijadikan sampel penelitian dari tahun 2009, 2010, dan 2011.

Metode pengumpulan datanya yaitu penelitian pustaka dan penelitian lapangan. Adapun metode analisis data yang digunakan adalah analisis regresi sederhana sebagai berikut:

$\mathrm{Y}=\mathrm{a}+\mathrm{bX}+\mathrm{e}$

Dimana :

$\mathrm{Y} \quad=$ Hasil penjualan Suku Cadang ( Rp )

$\mathrm{X}=\operatorname{Promosi}(\mathrm{Rp})$ 
a $=$ intercept $($ constanta $)$

$\mathrm{b} \quad=$ Koefisien regresi

e $\quad=$ Error term yang biasanya dianggap konstan

\section{HASIL DAN PEMBAHASAN}

Persentase Biaya Promosi untuk Tahun 2009, 2010, 2011

\begin{tabular}{|c|c|c|}
\hline \multirow{2}{*}{ Tahun } & \multicolumn{2}{|c|}{ Jumlah } \\
\cline { 2 - 3 } & $\begin{array}{c}\text { Biaya } \\
\text { Promosi }\end{array}$ & Persentase \\
\hline 2009 & 9.820 .000 & 24,36 \\
2010 & 14.950 .000 & 37,09 \\
2011 & 15.540 .000 & 38,55 \\
\hline Jumlah & 40.310 .000 & 100,00 \\
\hline
\end{tabular}

Tabel di atas, menunjukkan bahwa penyebaran data biaya promosi cukup variatif. Dari tiga tahun pengamatan yaitu dimulai tahun 2009, 2010, dan 2011, dapat terlihat pada tabel di atas bahwa pada tahun 2009 sampai dengan 2011 penyebaran data biaya promosi pada Bengkel Jakarta Kecamatan Sukamaju yang dikeluarkan mengalami peningkatan tiap tahunnya. Dimana besar persentase tiap tahunnya biaya promosi yang dikeluarkan oleh bengkel Jakarta Kecamatan Sukamaju yaitu 24,36\% untuk tahun 2009, 37,09\% untuk tahun 2010, dan 38,55\% untuk tahun 2011. Dengan demikian biaya promosi yang tertinggi yang dikeluarkan oleh bengkel Jakarta Kecamatan Sukamaju yaitu pada tahun 2011 sebesar 38,55\%. Hal ini disebabkan tingkat kebutuhan informasi dan pelayanan oleh masyarakat akan kualitas suku cadang yang ditersedia dalam hal ini oleh bengkel Jakarta Kecamatan Sukamaju dari tahun ke tahun mengalami perubahan yang disesuaikan dengan berbagai varian produk dalam hal ini kendaraan bermotor dari tahun ketahun mengalami perubahan.

Persentase Daftar Hasil Penjualan untuk Tahun 2009, 2010, 2011.

\begin{tabular}{|c|c|c|}
\hline \multirow{2}{*}{ Tahun } & \multicolumn{2}{|c|}{ Jumlah } \\
\cline { 2 - 3 } & Penjualan & Persentase \\
\hline 2009 & 185.200 .000 & 27,91 \\
2010 & 234.000 .000 & 35,27 \\
2011 & 244.300 .000 & 36,82 \\
\hline Jumlah & 663.500 .000 & 100,00 \\
\hline
\end{tabular}

Tabel di atas, menunjukkan bahwa penyebaran data penjualan cukup variatif. Dari tiga tahun pengamatan yaitu dimulai tahun 2009, 2010, dan 2011, dapat terlihat pada tabel 2 bahwa pada tahun 2009 sampai dengan 2011 penyebaran data penjualan pada Bengkel Jakarta Kecamatan Sukamaju yang dikeluarkan mengalami peningkatan tiap tahunnya. Dimana besar persentase tiap tahunnya hasil penjualan yang dihasilkan oleh bengkel Jakarta Kecamatan Sukamaju yaitu sebesar 27,91\% untuk tahun 2009, $35,27 \%$ untuk tahun 2010, dan 36,82\% untuk tahun 2011. Dengan demikian hasil penjualan yang tertinggi yang dihasilkan oleh bengkel Jakarta Kecamatan Sukamaju yaitu pada tahun 2011 sebesar 36,82\%. Hal ini diikuti dengan biaya promosi yang juga meningkat untuk tiap tahunnya. Dengan meningkatnya biaya promosi yang dilakukan oleh bengkel Jakarta pada tiap tahunnya ternyata dapat mempengaruhi hasil penjualan yang juga ikut meningkat untuk tiap tahunnya, ini berarti promosi yang di lakukan oleh bengkel Jakarta Kecamatan Sukamaju dapat di nilai efektif. 


\section{Analisis Pengaruh Biaya Promosi terhadap Penjualan}

Untuk mengetahui pengaruh dari biaya promosi terhadap penjualan suku cadang pada bengkel Jakarta Kecamatan Sukamaju dapat ditentukan dari persamaan regresi dengan bantuan SPSS 18.

\section{Penentuan Persamaan Regresi}

Berdasarkan hasil perhitungan peroleh persamaan regresi sebagai berikut :

$\mathrm{Y}=8,6667+0,701$ Biaya Promosi

Dimana masing-masing regresi tersebut mempunyai arti sebagai berikut :

$\mathrm{a}=8,6667$

Mempunyai arti Biaya Promosi $=0$ maka

Penjualan mengalami penurunan kenaikan 8,6667 .

$\mathrm{b}=0,998$ Biaya Promosi

Artinya jika variabel biaya promosi naik sebesar satu satuan, maka volume penjualan akan meningkat sebesar 0,998 satuan

dan mempunyai pengaruh positif terhadap penjualan.

\section{Koefisien Determinasi}

Analisis ini digunakan untuk mengetahui besarnya proporsi sumbangan dengan variabel bebas yaitu biaya promosi terhadap variabel dependen / variabel terikat yaitu Penjualan. Berdasarkan hasil perhitungan pada lampiran 2 diketahui:

R Square $\left(R^{2}\right)$ sebesar 0,995 artinya bahwa variasi perubahan variabel terikat yakni (volume penjualan) sebesar 99,5\% disebabkan oleh variabel bebas biaya promosi. Sedangkan sisanya sebesar
$0,5 \%$ disebabkan oleh variabel lain yang tidak teridentifikasi kedalam model.

\section{Pengujian Secara Simultan (Uji F)}

Pengujian ini dimaksud untuk mengetahui bagaimana variabel bebas yaitu biaya promosi secara simultan berpengaruh terhadap variabel dependen/variabel terikat yaitu penjualan.

Adapun langkah-langkah pengujiannya adalah sebagai berikut :

1. $\mathrm{H}_{\mathrm{o}}: \mathrm{B}_{\mathrm{i}}=0$, berarti tidak ada pengaruh antara variabel biaya promosi terhadap penjualan.

$\mathrm{H}_{\mathrm{a}}: \mathrm{B}_{\mathrm{i}} \neq 0$, berarti ada pengaruh antara variabel biaya promosi terhadap penjualan.

2. Level Of signifikan pada tingkat $\alpha=5 \%$

$\mathrm{F}_{\text {tabel }}$ dengan tingkat keyakinan $95 \%$ dan df (k-1) dan (n-k)

3. $\mathrm{F}_{\text {hitung }}<\mathrm{F}_{\text {tabel }}$ berarti $\mathrm{H}_{\mathrm{o}}$ diterima $\mathrm{H}_{\mathrm{a}}$ ditolak $\mathrm{F}_{\text {hitung }}>\mathrm{F}_{\text {tabel berarti }} \mathrm{H}_{\mathrm{a}}$ diterima $\mathrm{H}_{\mathrm{o}}$ ditolak

Dari hasil perhitungan diketahui bahwa : $\mathrm{F}_{\text {hitung }}=203,714>\mathrm{F}_{\text {tabel }}=18,51$ atau tingkat signifikan sebesar 0,045 lebih kecil jika dibandingkan dengan tingkat $\alpha=5 \%$ berarti bahwa biaya promosi secara simultan berpengaruh signifikan terhadap variabel dependen/variabel terikat yaitu penjualan.

\section{Pengujian Secara Partial (Uji t) untuk variabel biaya promosi}

Pengujian secara partial ( uji $-\mathrm{t}$ ) dimaksud untuk mengetahui tingkat signifikan antara variabel terikat secara statistik adalah sebagai berikut :

a. $H_{0}: B_{1}=0$, Variabel Pesanan tidak berpengaruh terhadap Volume Penjualan.

b. $H_{a}: B_{1} \neq 0$ Variabel Pesanan berpengaruh terhadap Volume Penjualan.

c. Level Of signifikan pada tingkat $\alpha=5 \%$ 
d. $t_{\text {tabel }}$ pada derajat signifikan dengan pendekatan uji hipotesis dua sisi dan derajat kebebasan n-k.

e. $\mathrm{T}_{\text {hitung }}<\mathrm{T}$ tabel berarti $\mathrm{H}_{\mathrm{o}}$ di terima dan $\mathrm{H}_{\mathrm{a}}$ ditolak $\mathrm{T}_{\text {hitung }}>\mathrm{T}_{\text {tabel }}$ berarti $\mathrm{H}_{\mathrm{a}}$ diterima dan $\mathrm{H}_{\mathrm{o}}$ di tolak

Dari hasil perhitungan di ketahui bahwa : variabel biaya promosi menghasilkan nilai $t_{\text {hitung }}=$ $14,273>\mathrm{t}_{\text {tabel }}=12,706$ atau tingkat signifikan sebesar 0,045 lebih kecil jika dibandingkan dengan tingkat $\alpha=5 \%$

Berdasarkan hasil perhitungan tersebut menunjukkan bahwa ada pengaruh yang nyata antara biaya promosi terhadap penjualan.

Berdasarkan hasil uji secara simultan (Uji F) dalam analisis regresi sedrhana pada penelitian ini diketahui bahwa tingkat signifikan sebesar 0,045 lebih kecil jika dibandingkan dengan tingkat $\alpha=$ $5 \%$ berarti bahwa variabel bebas biaya promosi secara simultan mempunyai pengaruh yang signifikan terhadap variabel dependen/variabel terikat yaitu penjualan.

Berdasarkan hasil regresi linear berganda untuk uji t diketahui bahwa variabel biaya promosi mempunyai pengaruh positif sebesar 0,998 atau 99,8\% dengan signifikan tingkat signifikan untuk variabel yaitu (biaya promosi $=0,045$ ). Dari hasil tersebut bahwa faktor.

Dengan demikian, hipotesis penelitiaan ini yang menduga bahwa promosi mempunyai pengaruh yang signifikan terhadap hasil penjualan Suku Cadang Pada Bengkel “ Jakarta " Sukamaju adalah terbukti kebenarannya.

\section{SIMPULAN}

1) Secara parsial variabel biaya promosi dari hasil perhitungan diperoleh angka thitung sebesar
14,237 > t tabel 12,706 sehingga Ha diterima dan Ho ditolak. Artinya ada hubungan linier antara variabel biaya promosi terhadap penjualan, yaitu 0,998 atau 99,8\% dianggap signifikan.

2) Secara simultan variabel biaya promosi berpengaruh secara signifikan terhadap penjualan sebesar 203,714 dengan signifikansi 0,045.

3) Hipotesis penelitiaan ini yang menduga bahwa promosi mempunyai pengaruh yang signifikan terhadap hasil penjualan Suku Cadang Pada Bengkel " Jakarta " Sukamaju adalah terbukti kebenarannya.

4) Suksesnya kegiatan penjualan yang dilakukan oleh suatu perusahaan tidak hanya dipengaruhi oleh kualitas produk yang dipasarkannya, kebijaksanaan harga yang tepat, pelayanan distribusi yang tepat, tetapi juga dipengaruhi oleh promosi penjualan yang dilakukan artinya promosi sangat penting bagi suatu perusahaan karena merupakan alat komunikasi antar perusahaan dan pasar atau produsen dan konsumen.

\section{DAFTAR PUSTAKA}


